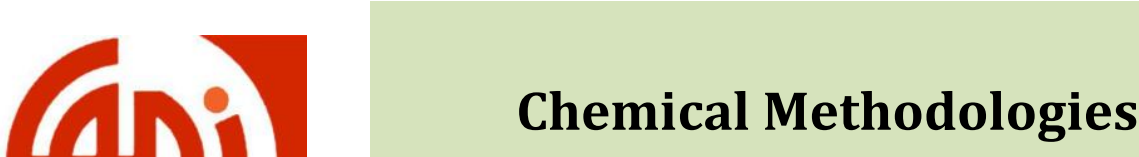 \\ Journal homepage: http://chemmethod.com
}

Original Research article

\section{Simultaneous Determination of Ramipril and Amlodipine Besylate in Tablet Dosage form by First Order Derivative Spectrophotometric Method}

\author{
Ashok B. Patela, Hina M. Jadava,*, Amitkumar J. Vyasa, Ajay I. Patela, Nilesh K. Patela, Alpesh
} Chudasamab $^{\mathrm{b}}$

${ }^{a}$ B.K. Mody Government Pharmacy College, Polytechnic Campus, Near Aji Dam, Rajkot, Gujarat, India, Postal code: 360003

b Amneal pharmaceutical LLC, Murray Road, Hanover, NJ 07936, USA

\section{ARTICLE INFORMATION}

Received: 24 February 2020

Received in revised: 18 March 2020

Accepted: 05 April 2020

Available online: 01 July 2020

DOI: $\underline{10.33945 / S A M I / C H E M M .2020 .4 .8 ~}$

\section{KEYWORDS}

\section{Ramipril}

AmLodipine besylate

First order derivative method

UV spectrophotometry

ICH guideline

\begin{abstract}
The aim of present study was to develop a simple, precise, accurate and reproducible spectrophotometric method for simultaneous determination of ramipril and amlodipine besylate by UV-visible spectrophotometer using the first order derivative method. According to our present knowledge, no first order derivative method was reported so far. Thus, in present study it was decided to carryout first order derivative method and it was validated in compliance with ICH (Q2 R1) guideline. Ramipril and amlodipine besylate showed absorbance at the working wavelength of $211.87 \mathrm{~nm}$ (zero crossing point of amlodipine besylate) and $254.34 \mathrm{~nm}$ (zero crossing point of ramipril) respectively using distilled water as a diluent. Linearity was established over the concentration range of $2-25 \mu \mathrm{g} / \mathrm{mL}$ and $2-50 \mu \mathrm{g} / \mathrm{mL}$ for ramipril and amlodipine besylate with correlation coefficient 0.999 and 0.998 respectively. Accuracy was obtained between $99.91-101.06 \%$ and $99.66-100.66 \%$ for ramipril and amlodipine besylate respectively. LOD were found to be 0.078 $\mu \mathrm{g} / \mathrm{mL}$ and $0.059 \mu \mathrm{g} / \mathrm{mL}$ and LOQ were $0.239 \mu \mathrm{g} / \mathrm{mL}$ and $0.178 \mu \mathrm{g} / \mathrm{mL}$ for ramipril and amlodipine besylate respectively. The results revealed that the developed method is suitable for the routine analysis of determining of ramipril and amlodipine besylate in a tablet dosage form.
\end{abstract}

Copyright (C) 2020 by SPC (Sami Publishing Company)

Chemical Methodologies: http://www.chemmethod.com/

*Corresponding author: E-mail: hinajadav1991@gmail.com, B.K. Mody Government Pharmacy College, Polytechnic Campus, Near Aji Dam, Rajkot, Gujarat, India, Postal code: 360003,Tel: +7984738023 


\section{Graphical Abstract}
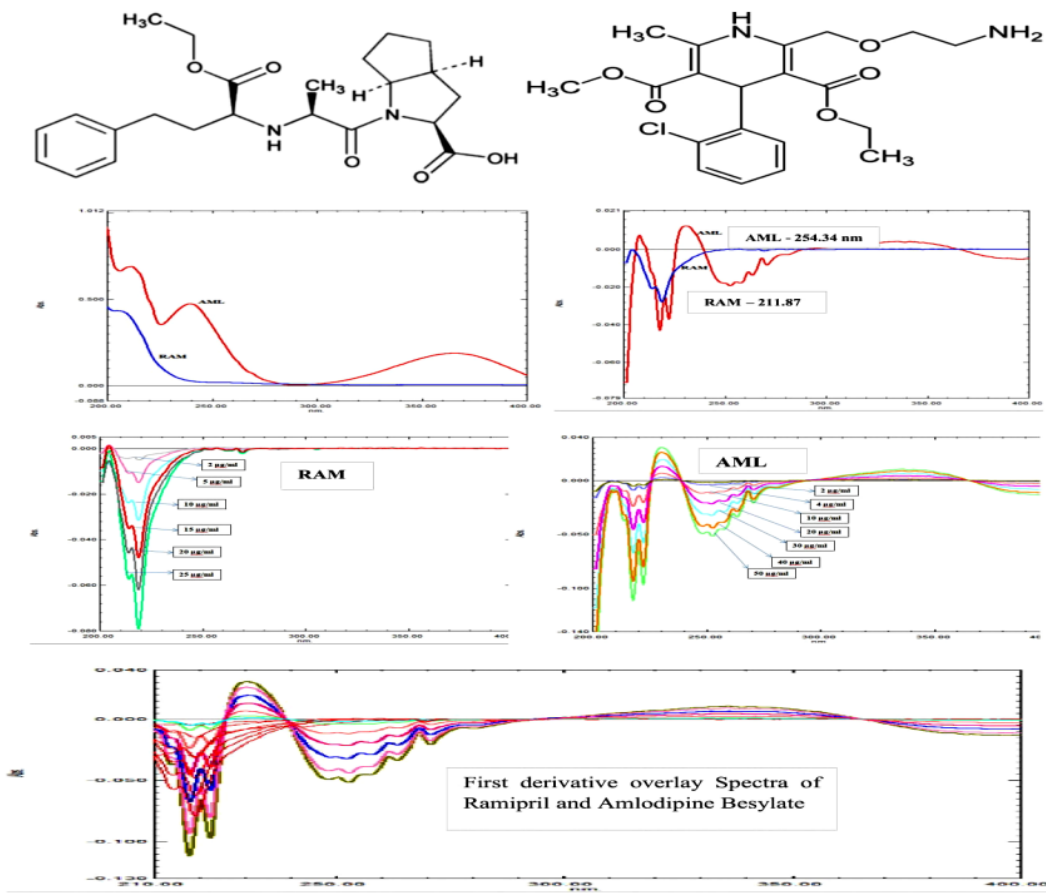

\section{Introduction}

Ramipril (RAM) is $\quad(2 \mathrm{~S}, 3 \mathrm{As}, 6 \mathrm{As})-1-[(2 \mathrm{~S})-2-[[(2 \mathrm{~S})-1$-ethoxy-1-oxo-4phenylbutan-2yl]amino]propanoyl]-3,3a,4,5,6,6a-hexahydro-2H-cyclopenta[b] pyrrole-2-carboxylic acid [1]. It is angiotensin converting enzyme (ACE) inhibitor, indicated for the treatment of hypertension, heart failure and myocardial infarction. Structure of the ramipril is shown in Figure 1 [2].

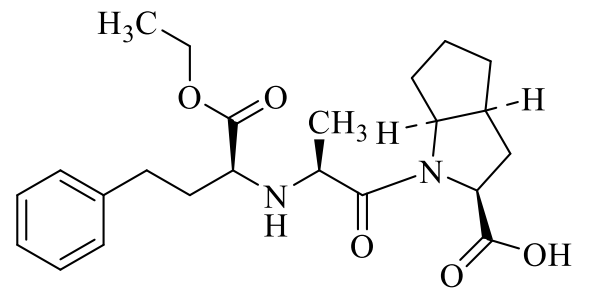

Figure 1. Structure of ramipril 
Amlodipine besylate (AML) is benzenesulfonic acid; 3-0-ethyl 5-0-methyl 2-(2-aminoethoxymethyl)4-(2-chlorophenyl)-6methyl-1, 4-dihydropyridine-3, 5-dicarboxylate, It is a Calcium channel blocker, indicated for the treatment of hypertension and angina. Structure of amlodipine besylate is illustrated in Figure 2 [3].

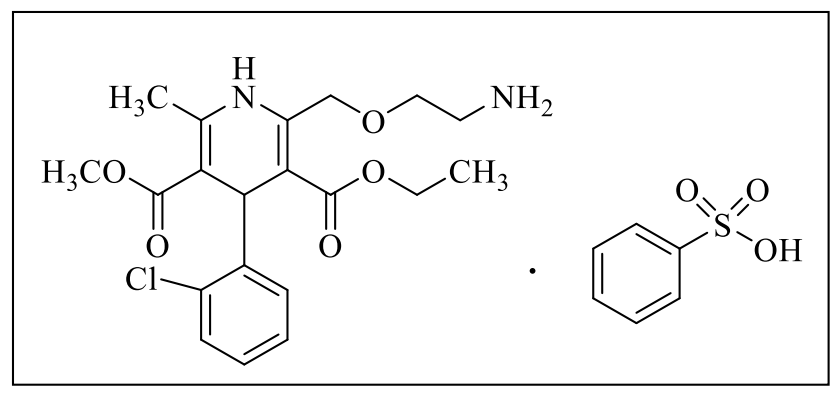

Figure 2. Structure of amlodipine besylate

The drug combination offers more beneficial effects over single drug therapy in the treatment of hypertension in patients [4]. Various analytical methods are available to determine the ramipril and amlodipine besylate individually and in combination. It includes simultaneous equation methods [5], RP-HPLC [6-8], HPTLC [9] for combination of both drugs and simultaneous equation methods [10, 11], RP-HPLC [12-16], stability indicating HPLC [17, 18], UPLC [19], LC-MS [20], Chemometry [21], absorption maxima method [22] and area under curve method for ramipril and amlodipine besylate alone and with combination with others are available.

According to our present knowledge, no first order derivative method was reported so far. Therefore, in this study it was decided to carry out the first order derivative method. This method was validated in compliance with the ICH guideline (Q2 R1) [23]. First order derivative spectroscopy was found to be more selective, accurate, precise and simple for the estimation.

\section{Experimental}

\section{Chemicals and reagents}

Ramipril, amlodipine besylate and distilled water were provided by the B.K. Mody government pharmacy college. UV-visible spectrophotometer (UV-1800 Shimadzu) used, data were processed using UV Prob (version 2.60) software.

\section{Preparation of standard stock solution}

Standard stock solution of $100 \mu \mathrm{g} / \mathrm{mL}$ for ramipril and $200 \mu \mathrm{g} / \mathrm{mL}$ for the amlodipine besylate was prepared in distilled water as diluent. 


\section{Selection of wavelength}

By appropriate dilutions from the standard stock solution, $10 \mu \mathrm{g} / \mathrm{mL}$ and $20 \mu \mathrm{g} / \mathrm{mL}$ of the ramipril and amlodipine besylate respectively were separately prepared and scanned in the UV range 200$400 \mathrm{~nm}$. The overlain zero-order absorption spectra of both drugs were obtained. These absorbance spectra were converted to the first order derivative spectra. After observing overlay first order derivative spectra with scaling factor 1 and $\Delta \lambda 2$ for ramipril and amlodipine besylate, zero crossing points of drugs were selected. The first wavelength selected was $211.87 \mathrm{~nm}$ (zero crossing of amlodipine besylate), where ramipril showed considerable absorbance. The second wavelength selected was $254.34 \mathrm{~nm}$ (zero crossing of ramipril), where amlodipine besylate showed considerable absorbance.

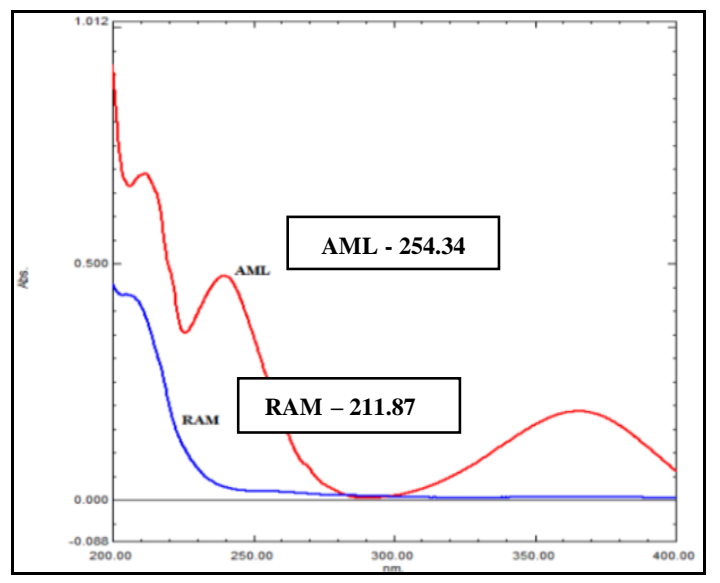

(a) Zero order specta

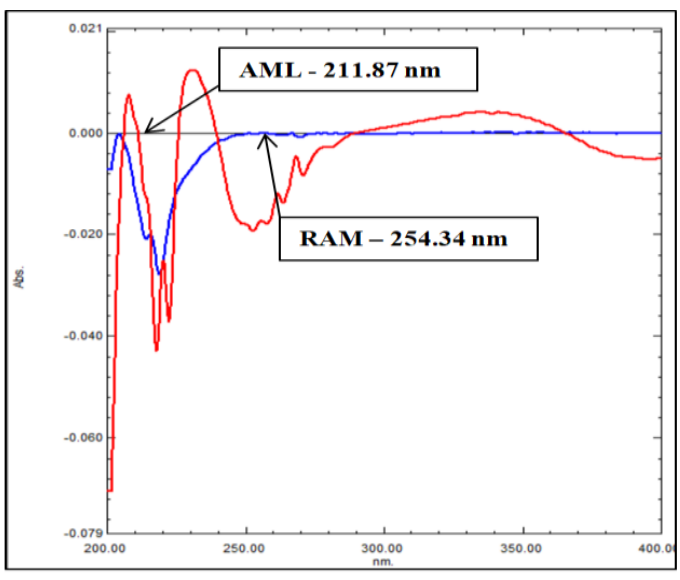

(b) First order derivative spectra

Figure 3. Wavelength selection spectrum of RAM and AML

\section{Method validation}

\section{Linearity}

The standard stock solution was diluted appropriately to obtain the concentration of 2, 5, 10,15, 20, and $25 \mu \mathrm{g} / \mathrm{mL}$ of ramipril and 2, 4, 10, 20, 30, 40 and $50 \mu \mathrm{g} / \mathrm{mL}$ of amlodipine besylate in $10 \mathrm{~mL}$ volumetric flask, and diluted up to the mark with distilled water.

\section{Specificity}

Specificity was performed under 6 replicates at concentration $10 \mu \mathrm{g} / \mathrm{mL}$ of ramipril and $20 \mu \mathrm{g} / \mathrm{mL}$ of amlodipine besylate with and without addition of excipients to check the interference of excipients. 


\section{LOD and LOQ}

The limit of detection (LOD) and limit of quantification (LOQ) were calculated by formula. The calibration curve was repeated five times and standard deviation (SD) of the intercepts was calculated.

LOD $=3.3 \times$ Standard deviation/Slope

LOQ = $10 \times$ Standard deviation/Slope

\section{Accuracy}

The accuracy of the method was performed in triplicate at three different concentration levels of 50, 100 and $150 \%(15,20$ and $25 \mu \mathrm{g} / \mathrm{mL}$ for ramipril and 30, 40 and $50 \mu \mathrm{g} / \mathrm{mL}$ for amlodipine besylate). Study was performed by spiking above concentration to placebo.

The accuracy of method was evaluated by calculating percentage recovery.

\section{Precision}

Repeatability was performed under 6 replicates at concentration of $10 \mu \mathrm{g} / \mathrm{mL}$ of ramipril and 20 $\mu \mathrm{g} / \mathrm{mL}$ of amlodipine besylate. Intra-day and inter-day variations of ramipril and amlodipine besylate were performed in triplicate at three different concentration levels $50,100,150 \%(5,10$, and $15 \mu \mathrm{g} / \mathrm{mL}$ and 10, 20, $30 \mu \mathrm{g} / \mathrm{mL}$ for ramipril and amlodipine besylate respectively). Results are expressed in the form of RSD.

\section{Robustness}

The robustness of method was established by introducing small change in experimental condition like wavelength. The changes made in wavelength $\pm 1 \mathrm{~nm}(211.87,210.87,212.87 \mathrm{~nm}$ for ramipril and 254.34, 253.34, 255.34 $\mathrm{nm}$ for amlodipine besylate).

\section{Assay of tablet dosage form}

Twenty tablets was accurately weighed and finely powdered. A quantity of the powder equivalent to $10 \mathrm{mg}$ ramipril and $20 \mathrm{mg}$ amlodipine besylate was transferred into $100 \mathrm{~mL}$ volumetric flask. Then add $60 \mathrm{~mL}$ of distilled water and sonicate for $10 \mathrm{~min}$, make up the volume with distilled water. Then passed it through whatman filter paper. From this solution made $10 \mu \mathrm{g} / \mathrm{mL}$ and $20 \mu \mathrm{g} / \mathrm{mL}$ solution for ramipril and amlodipine besylate respectively.

\section{Results and discussion}

Linearity: The calibration curve was obtained for ramipril and amlodipine besylate in the range of 2-25 $\mu \mathrm{g} / \mathrm{mL}$ and $2-50 \mu \mathrm{g} / \mathrm{mL}$ and the correlation coefficient was found to be 0.999 and 0.998 respectively. 
This method is fond linear. Linearity spectra and graph is revelead in Figure 5 and data is shown in Table 1.

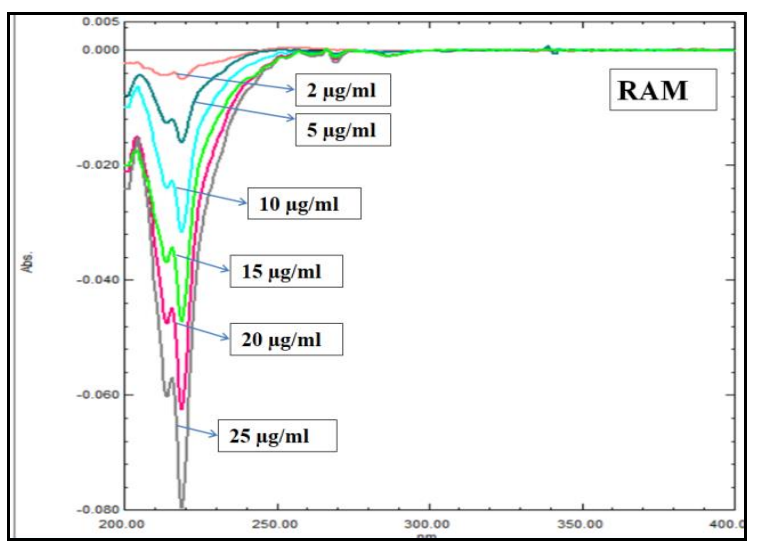

(A)

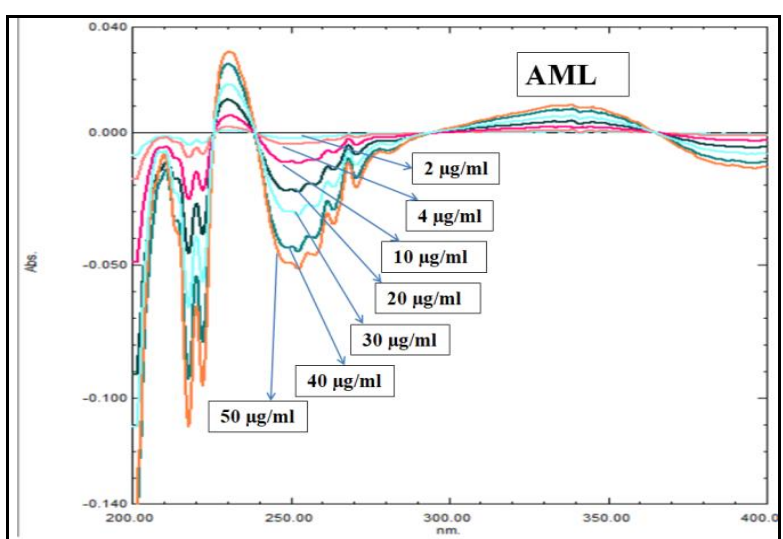

(B)

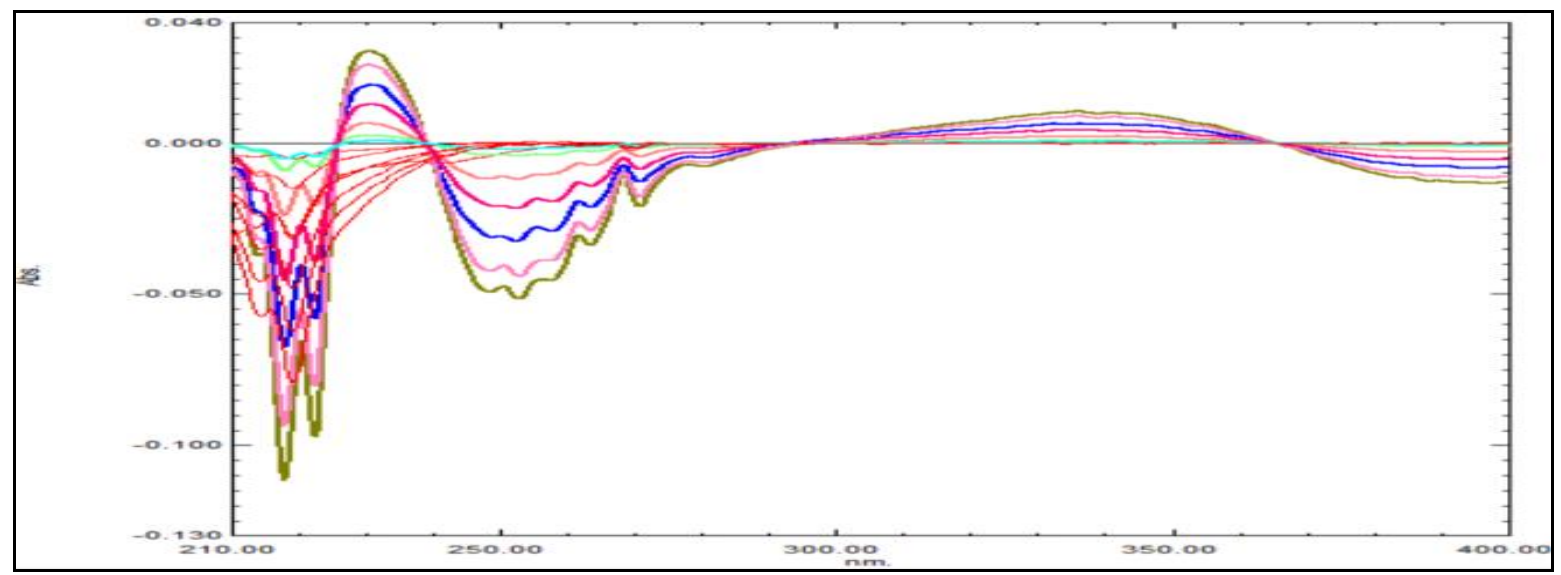

(C)

Figure 4. Linearity spectra for (A) RAM, (B) AML, (C) Overlay spectra
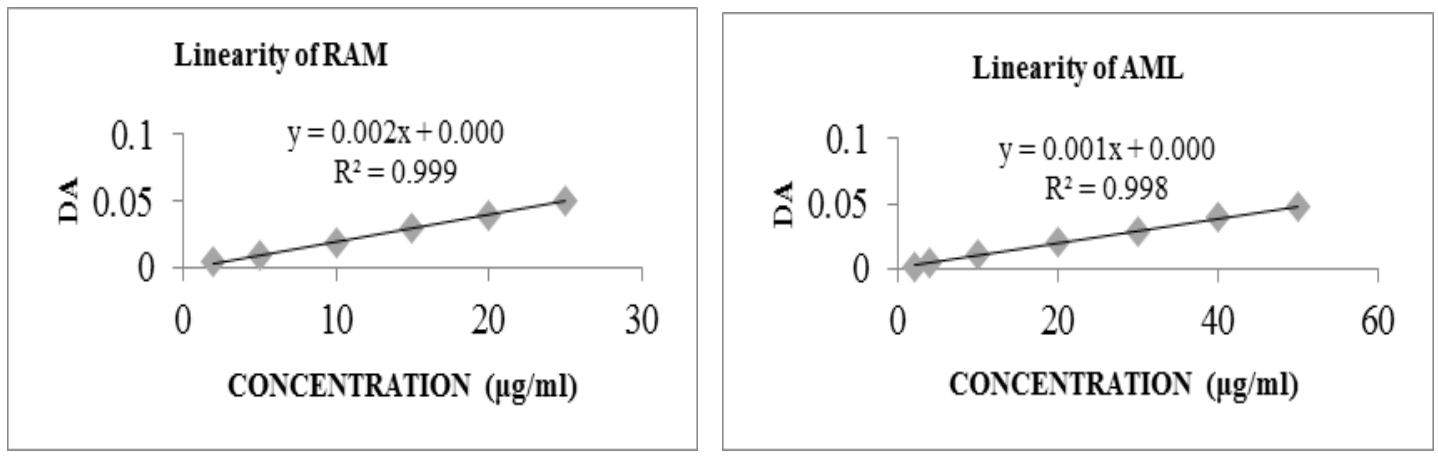

Figure 5. Linearity graphs for ramipril and amlodipine besylate 
Table 1. Linearity for ramipril and amlodipine besylate

\begin{tabular}{|c|c|c|c|}
\hline \multicolumn{2}{|c|}{ Ramipril } & \multicolumn{2}{c|}{ Amlodipine besylaye } \\
\hline Conc $(\boldsymbol{\mu g} / \mathbf{m L})$ & Absorbance & Conc $(\boldsymbol{\mu g} / \mathbf{m L})$ & Absorbance \\
\hline 2 & 0.0040 & 2 & 0.0022 \\
\hline 5 & 0.0102 & 4 & 0.0041 \\
\hline 10 & 0.0190 & 10 & 0.0110 \\
\hline 15 & 0.0300 & 20 & 0.0203 \\
\hline 20 & 0.0392 & 30 & 0.0281 \\
\hline 25 & 0.0500 & 40 & 0.0400 \\
\hline- & - & 50 & 0.0473 \\
\hline
\end{tabular}

Specificity: Excipients interference is not observed at the working wavelength $211.87 \mathrm{~nm}$ for ramipril and $254.34 \mathrm{~nm}$ for amlodipine besylate, and \% interference was found less than $0.5 \%$. Thus method is specific. The data of specificity is given in Table 2 .

Table 2. Specificity study for ramipril and amlodipine besylate

\begin{tabular}{|c|c|c|c|c|c|c|c|}
\hline & \multirow{3}{*}{$\begin{array}{c}\text { Conc } \\
(\mu \mathrm{g} / \mathrm{mL}) \\
(\mathrm{n}=6)\end{array}$} & \multicolumn{2}{|c|}{ Absorbance } & \multicolumn{2}{|c|}{ Concentration $(\mu \mathrm{g} / \mathrm{mL})$} & \multirow[t]{3}{*}{ Difference } & \multirow{3}{*}{$\begin{array}{c}\% \\
\text { Interference }\end{array}$} \\
\hline & & $\begin{array}{c}\text { With } \\
\text { excipients }\end{array}$ & $\begin{array}{c}\text { Without } \\
\text { excipients }\end{array}$ & $\begin{array}{c}\text { With } \\
\text { excipients }\end{array}$ & $\begin{array}{c}\text { Without } \\
\text { excipients }\end{array}$ & & \\
\hline & & \multicolumn{2}{|c|}{ Mean \pm SD } & \multicolumn{2}{|c|}{ Mean \pm SD } & & \\
\hline RAM & 10 & \multicolumn{2}{|c|}{$0.019 \pm 0.0$} & \multicolumn{2}{|c|}{$9.5 \pm 0.0$} & 0 & 0 \\
\hline AML & 20 & \multicolumn{2}{|c|}{$0.020 \pm 0.0$} & \multicolumn{2}{|c|}{$20 \pm 0.0$} & 0 & 0 \\
\hline
\end{tabular}

LOD and LOQ: LOD and LOQ were found to be $0.078 \mu \mathrm{g} / \mathrm{mL}$ and $0.239 \mu \mathrm{g} / \mathrm{mL}$ for ramipril and 0.059 and $0.178 \mu \mathrm{g} / \mathrm{mL}$ for amlodipine besylate respectively.

Accuracy: This method was accurate and \% recovery was found in the range of 99.66-101.06\%. Therefore, the recovery of drugs are acceptable as shown in Table 3.

Table 3. Accuracy study for ramipril and amlodipine besylate

\begin{tabular}{|c|c|c|c|c|c|c|}
\hline \multirow{2}{*}{$\begin{array}{c}\text { \% Recovery } \\
\text { level }\end{array}$} & \multicolumn{2}{|c|}{ Target Conc. $(\boldsymbol{\mu g} / \mathbf{m L})$} & \multicolumn{2}{c|}{ Spiked Conc. $(\boldsymbol{\mu g} / \mathbf{m L})$} & \multicolumn{2}{c|}{$\begin{array}{c}\text { Mean recovery } \\
(\mathbf{n}=3)\end{array}$} \\
\cline { 2 - 7 } & RAM & AML & RAM & AML & RAM & AML \\
\hline 50 & 10 & 20 & 5 & 10 & $100.44 \%$ & $100.21 \%$ \\
\hline 100 & 10 & 20 & 10 & 20 & $99.9 \%$ & $99.66 \%$ \\
\hline 150 & 10 & 20 & 15 & 30 & $101.06 \%$ & $100.66 \%$ \\
\hline
\end{tabular}

Precision: Repeatability and intermediate precision express in term of RSD. The result is summarized in Table 4 and 5 respectively.

Table 4. Repeatability study for ramipril and amlodipine besylate

\begin{tabular}{|c|c|c|c|}
\hline Drug & Concentration $(\boldsymbol{\mu g} / \mathbf{m L})(\mathbf{n = 6 )}$ & $\begin{array}{c}\text { Concentration found }(\boldsymbol{\mu g} / \mathbf{m L}) \\
\text { Mean } \pm \text { SD }\end{array}$ & RSD \\
\hline RAM & 10 & $9.65 \pm 0.00025$ & 1.294 \\
\hline AML & 20 & $20.2 \pm 0.00013$ & 0.680 \\
\hline
\end{tabular}


Table 5. Intermediate study for ramipril and amlodipine besylate

\begin{tabular}{|c|c|c|c|c|c|}
\hline \multicolumn{2}{|c|}{ Precision } & \multicolumn{2}{c|}{ Intra-day (n=3) } & \multicolumn{2}{c|}{ Inter-day (n=3) } \\
\hline \multirow{2}{*}{ Drug } & Level (\%) & $\begin{array}{c}\text { Absorbance (Mean } \\
\mathbf{\pm} \text { SD) }\end{array}$ & RSD & $\begin{array}{c}\text { Absorbance (Mean } \pm \\
\text { SD) }\end{array}$ & RSD \\
\hline \multirow{3}{*}{ RAM } & 50 & $0.0101 \pm 0.00017$ & 1.7406 & $0.0098 \pm 0.00018$ & 1.8690 \\
\cline { 2 - 6 } & 100 & $0.0197 \pm 0.00027$ & 1.3726 & $0.0201 \pm 0.00028$ & 1.4065 \\
\cline { 2 - 6 } & 150 & $0.0305 \pm 0.00035$ & 1.1566 & $0.0300 \pm 0.00040$ & 1.3360 \\
\hline \multirow{3}{*}{ AML } & 50 & $0.0097 \pm 0.00005$ & 0.5237 & $0.0101 \pm 0.00005$ & 0.5697 \\
\cline { 2 - 6 } & 100 & $0.0205 \pm 0.00014$ & 0.7087 & $0.0200 \pm 0.00015$ & 0.7624 \\
\cline { 2 - 6 } & 150 & $0.0309 \pm 0.00031$ & 1.0192 & $0.0312 \pm 0.00028$ & 1.0900 \\
\hline
\end{tabular}

Robustness: Making a deliberate change in wavelength was take place and RSD of absorbance found to be less than 2 , specify that the method was robust. The results are shown in Table 6 .

Table 6. Robustness study for ramipril and amlodipine besylate

\begin{tabular}{|c|c|c|c|}
\hline Conc $(\boldsymbol{\mu g} / \mathbf{m L})$ & \multicolumn{3}{|c|}{ Absorbance at different wavelength (ramipril) } \\
\hline \multirow{3}{*}{10} & $\mathbf{2 1 1 . 3 7} \mathbf{~ n m}$ & $\mathbf{2 1 1 . 8 7} \mathbf{~ n m}$ & $\mathbf{2 1 2 . 3 7} \mathbf{~ n m}$ \\
\cline { 2 - 4 } & 0.0195 & 0.0196 & 0.0192 \\
\cline { 2 - 4 } & 0.0191 & 0.0192 & 0.0193 \\
\cline { 2 - 4 } & 0.0195 & 0.0195 & 0.0199 \\
\hline Mean \pm SD & $0.0193 \pm 0.00023$ & $0.0194 \pm 0.00020$ & $0.0196 \pm 0.00020$ \\
\hline RSD & 1.1924 & 1.0711 & 1.0748 \\
\hline Conc $(\boldsymbol{\mu g} / \mathbf{m L})$ & Absorbance at different wavelength (amlodipine besylate) \\
\hline \multirow{3}{*}{20} & $253.84 \mathrm{~nm}$ & $254.34 \mathrm{~nm}$ & $254.84 \mathrm{~nm}$ \\
\cline { 2 - 4 } & 0.0203 & 0.0206 & 0.0203 \\
\cline { 2 - 4 } & 0.0200 & 0.0203 & 0.0206 \\
\cline { 2 - 4 } & 0.0201 & 0.0204 & 0.0205 \\
\hline Mean \pm SD & $0.0201 \pm 0.00015$ & $0.0204 \pm 0.00015$ & $0.0204 \pm 0.00015$ \\
\hline RSD & 0.7587 & 0.7475 & 0.7463 \\
\hline
\end{tabular}

\section{Assay of tablet dosage form}

\% Drug content of tablet dosage form of ramipril and amlodipine besylate was found between 99.33-101.00\%. The data is given in Table 7.

Table 7. Assay

\begin{tabular}{|c|c|c|c|c|c|c|}
\hline \multirow{2}{*}{$\begin{array}{c}\text { Conc } \\
(\boldsymbol{\mu} \mathbf{\mu g} / \mathbf{m L})\end{array}$} & \multicolumn{2}{|c|}{$\begin{array}{c}\text { Absorbance }(\mathbf{n}=5) \\
\text { Mean } \pm \text { SD }\end{array}$} & \multicolumn{2}{c|}{$\begin{array}{c}\text { Conc. Found } \\
\text { Mean } \pm \text { SD }\end{array}$} & \multicolumn{2}{c|}{ \% Drug content } \\
\cline { 2 - 7 } RAM:AML & RAM & AML & RAM & AML & RAM & AML \\
\hline \multirow{2}{*}{$(10: 20)$} & 0.0198 & $0.0202 \pm$ & $9.93 \pm$ & $20.20 \pm$ & 99.33 & 101.00 \\
\hline
\end{tabular}

\section{Conclusions}

The developed method for the spectrophotometric determination of the ramipril and amlodipine besylate was found to be simple, rapid, sensitive, reproducible specific, robust, with good accuracy and precision. As there was no interference of excipients at the working wavelength, it was very fast, with great reproducibility and good response. It allows reliably the analysis of the Ramipril and 
AmLodipine Besylate in binary mixture. Linearity were established over the concentration range of 2-

$25 \mu \mathrm{g} / \mathrm{mL}$ and 2-50 $\mu \mathrm{g} / \mathrm{mL}$ for ramipril and amlodipine besylate with correlation coefficient 0.999 and 0.998 respectively. Accuracy was obtained between $99.91-101.06 \%$ and $99.66-100.66 \%$ for ramipril and amlodipine besylate respectively. LOD were found to be $0.078 \mu \mathrm{g} / \mathrm{mL}$ and $0.059 \mu \mathrm{g} / \mathrm{mL}$ and LOQ were $0.239 \mu \mathrm{g} / \mathrm{mL}$ and $0.178 \mu \mathrm{g} / \mathrm{mL}$ for Ramipril and AmLodipine Besylate respectively.

\section{References}

[1] Indian pharmacopoeia, government of India, ministry of health \& family welfare; 8th Edition; Indian pharmacopoeia commission, Ghaziabad, 2018, Volume-II, Page No. 3090

[2] Rajput P.S., Kaur A., Gill Kaur N., Mittal K., Sarma G.S. J. Appl. Pharm. Sci, 2012, 2:160

[3] Indian pharmacopoeia, government of India, ministry of health \& family welfare; 8th Edition; Indian pharmacopoeia commission, Ghaziabad, 2018, Volume-II, Page No.1219

[4] Bhatt J.U., Shah D.A., Chhalotiya U.K., Bhatt K.K. Int. J. Institut. Pharm. Life Sci., 2013, 3:100

[5] Kumar M., Jindal M., Bhatt A., Pandurangan A., Malik A., Kaushik V., Upadhaya P.K., Arunachalam G. J. Pharm. Sci. Res., 2019, 11:667

[6] Dai S.Y., Qiu S.T., Fu C.M. J. Pharm. Ana.l, 2013, 3:440

[7] Kumar A.P.V., Kumar A., Nasare M., Rao V., Prasad V.V.I.N., Diwan P.V. J. Adv. Pharm. Educat. Res., 2012, 2:137

[8] Patel J., Patel M. J. Chem. Pharm. Res., 2014, 6:725

[9] Gupta K.R., Wankhede S.B., Tajne M.R., Wadodkar S.G. Asian J. Chem., 2007, 19:4177

[10] Kalra N., Choudhary S. Adv. J. Pharm. Life Sci. Res., 2013, 1:16

[11] Macêdo I.Y.L., Gil E.S., J. Anal. Pharm. Res., 2017, 4:1

[12] Yilmaz B. Int. J. Pharm. Sci. Rev. Res., 2010, 1:39

[13] Verma A.R., Sanmukha J.V., Reddy S.M. J. Chem. Pharm. Res., 2015, 7:1060

[14] Mayank J., Sukriti T., Vinay Kumar M., Sugat S., Saima S., Int. J. Pharm. Life Sci., 2010, 1:428

[15] Khazali E.A.A., Hasan N.S., Abd alwahab H.S., Ali I.K., World J. Pharm. Sci., 2017, 5:45

[16] Bhaisare M., Sahu K., Karthikeyan C., Moorthy N.S.H.N., Trivedi P. Latin Am. J. Pharm., 2011, 30:342

[17] Gandhi B.M., Kapuganti A.N.J., Vatchavai B.R., Sumanth K.S., Kogitapurapu V.K., Kolli S., Parimi H. Asian J. Biomed. Pharm. Sci., 2016, 6:14

[18] Kiarie-Makara M.W., Lee D-K., IOSR J. Pharm. Biol. Sci., 2016, 11:24

[19] Waghmare A.N., Muddukrishna B.S., , Vasantharaju S.G., Mintage J. Pharm. Med. sci., 2014, 3:22

[20] Ponneri V., Vasu B.R., Inamadugu J.K., Rao N.P., Vudagandala S. J. Pharm. Sci., 2012, 2:319

[21] Nagawalli D., Vaidhyalingam V., Santha A., Sankar A.S.K., Divya O. Acta Pharm., 2010, 60:141 
[22] Iftequar S., Swaroop L., Zaheer Z., Shahid M., Imran S., Dehghan M.H., Int. J. Drug Dev. Res., 2012, 4:286

[23] Guideline I.H.T., Validation of analytical procedures: text and methodology Q2 (R1). International Conference on Harmonization, IFPMA, Geneva, Swizerland, 2005

How to cite this manuscript: Ashok B. Patel, Hina M. Jadav*, Amitkumar J. Vyas, Ajay I. Patel, Nilesh K. Patel, Alpesh Chudasama, Simultaneous Determination of Ramipril and Amlodipine Besylate in Tablet Dosage form by First Order Derivative Spectrophotometric Method. Chemical Methodologies 4(4), 2020, 467-476. DOI:10.33945/SAMI/CHEMM.2020.4.8. 